\title{
Role of Radioprotectors in the Inhibition of DNA Damage and Modulation of DNA Repair After Exposure to Gamma-Radiation
}

\author{
Dharmendra Kumar Maurya and Thomas Paul Asir Devasagayam \\ Radiation Biology and Health Sciences Division, \\ Bhabha Atomic Research Centre, Mumbai, \\ India
}

\section{Introduction}

Radiation has been considered an enigma to the general public and the use of radiation for therapeutic and other uses has always been associated with some skepticism. Presently, ionizing radiation is being used in a large number of therapeutic, industrial and other applications apart from for the generation of nuclear power, developing new varieties of high-yielding crops and enhancing storage period of food materials. Radiation treatment is an important therapeutic option for a number of malignancies, but its use is frequently limited due to adverse effects on normal tissues because it generates reactive oxygen species (ROS) such as hydroxyl radical $(\mathrm{OH})$, superoxide radicals $\left(\mathrm{O}_{2^{-}}\right)$, singlet oxygen and peroxyl radicals (ROO) in irradiated tissue that induce several pathophysiological changes in the body. The goal of most cancer treatments is to maximize the antineoplastic effect while minimizing harmful side effects for the patient.

Due to the increased use of ionizing radiation in various aspects of human life, there is a need to develop an effective and non-toxic radioprotector. Radioprotectors are compounds that are designed to reduce the damage in normal tissues caused by radiation. These compounds are often antioxidants and must be present before or at the time of radiation for their effectiveness. Other agents, termed mitigators, may be used to minimize toxicity even after radiation has been delivered. Many natural and synthetic chemicals have been investigated in the recent past for their efficacy to protect against radiation-induced damage in biological systems (Maurya et al. 2006). Though a large number of compounds have been shown to be promising as radioprotectors in laboratory studies, few could pass the transition from bench to bedside. In fact, no radioprotective agent is now available, either alone or in combination to meet all the requisites of an ideal radioprotector. Amifostine is the only one that is currently in use having good radioprotection, even though there are reports about contraindications in some cases. Different radioprotectors offer protection to cellular molecules by different mechanisms (Maurya et al. 2006). Some of these compounds protect the target molecules because of their antioxidant mechanism by neutralizing the free radical, some enhances the cellular DNA repair (Maurya et al. 2005a; Maurya et al. 2005b), some modified the signaling pathways, some modulate the immune system and some contribute to a combination of all above mentioned mechanisms. 
Radiation-induced DNA double-strand breaks are believed to be important lesions and the key trigger leading to a series of cellular consequences related to cell killing, gene mutation, induction of chromosome aberrations and carcinogenesis. There are two major cellular intrinsic factors deciding the extent of DNA damage in the irradiated cells, i.e. the activity of antioxidant systems and the capacity of DNA repair. There are two distinct but complementary mechanisms for DNA DSB repair namely; non-homologous end joining (NHEJ) and homologous recombination (HR) involving various repair proteins to execute the repair process. When discussing about a single or a group of radioprotectors, one has to keep in mind that radioprotective effect is an ability of radioprotectors to inhibit indirect effect and to repair direct and indirect damages occurred in the cells after radiation exposure. Discussions of all the molecular steps are out of the chapter's scope. In this chapter we are going to discuss a series of consequences happening after irradiation, types of damages induced, possible role of radioprotectors in preventing DNA damage and modulating DNA repair. At the end the future prospects for radioprotectors in mitigation of radiation damage will be discussed.

\section{Consequences of radiation exposure on cells/ tissues and possible role of radioprotectors}

Exposure of living cells/ tissues to ionizing radiation causes damages by transfer of energy to atoms and molecules in the cellular structure. Ionizing radiation causes either excitation or ionization or both to atoms and molecules. These excitations and ionizations can lead to following events inside the cells/ tissues;

i. Generation of free radicals

ii. Breakage of chemical bonds

iii. Formation of new chemical bonds and cross-linkage between macromolecules.

iv. Damage to biomolecules (e.g. DNA, RNA, lipids, proteins) which regulate vital cell processes

To understand the mechanism of action of radioprotectors, an in-depth knowledge of fundamental radiobiological events happening during and shortly after irradiation in tissues and cells is essential. Scheme 1 depicts the series of events happening in cells/ tissues following radiation exposure. Radiation causes damage to cells/ tissues by both direct and indirect actions. During direct action, the radiation is directly causing irreparable damage to critical targets within the cell, such as DNA, RNA, proteins and lipids. In indirect action, radiation interacts with other molecules of the cell that are not critical targets but are close enough to pass on this damage, typically in the form of free radicals. Indirect action of ionizing radiation is due to free radicals, generated during radiolysis. Because body is composed of $>80 \%$ water, indirect effect is important due to the radiolytic products, mainly the hydroxyl free radical, which is an effective oxidant capable of breaking chemical bonds, initiating lipid peroxidation, in the nano- to microsecond timeframe. After radiation exposures following changes are observed in DNA at the molecular level namely single- or double-strand breaks (DSB), base damage, and DNA-DNA or DNA-protein cross-links (Maurya et al. 2006). If different damages following radiation exposure not repaired, they affect the cell structure and function. After DNA damage has occurred, a number of processes occur in the damaged cell, tissue, or organism, including activation of DNA repair, activation of signal transduction, expression of radiation response genes and stimulation of proliferation etc. These pathways can be important for cell or tissue recovery after radiation exposure but may also play a role in the development of toxicity. 


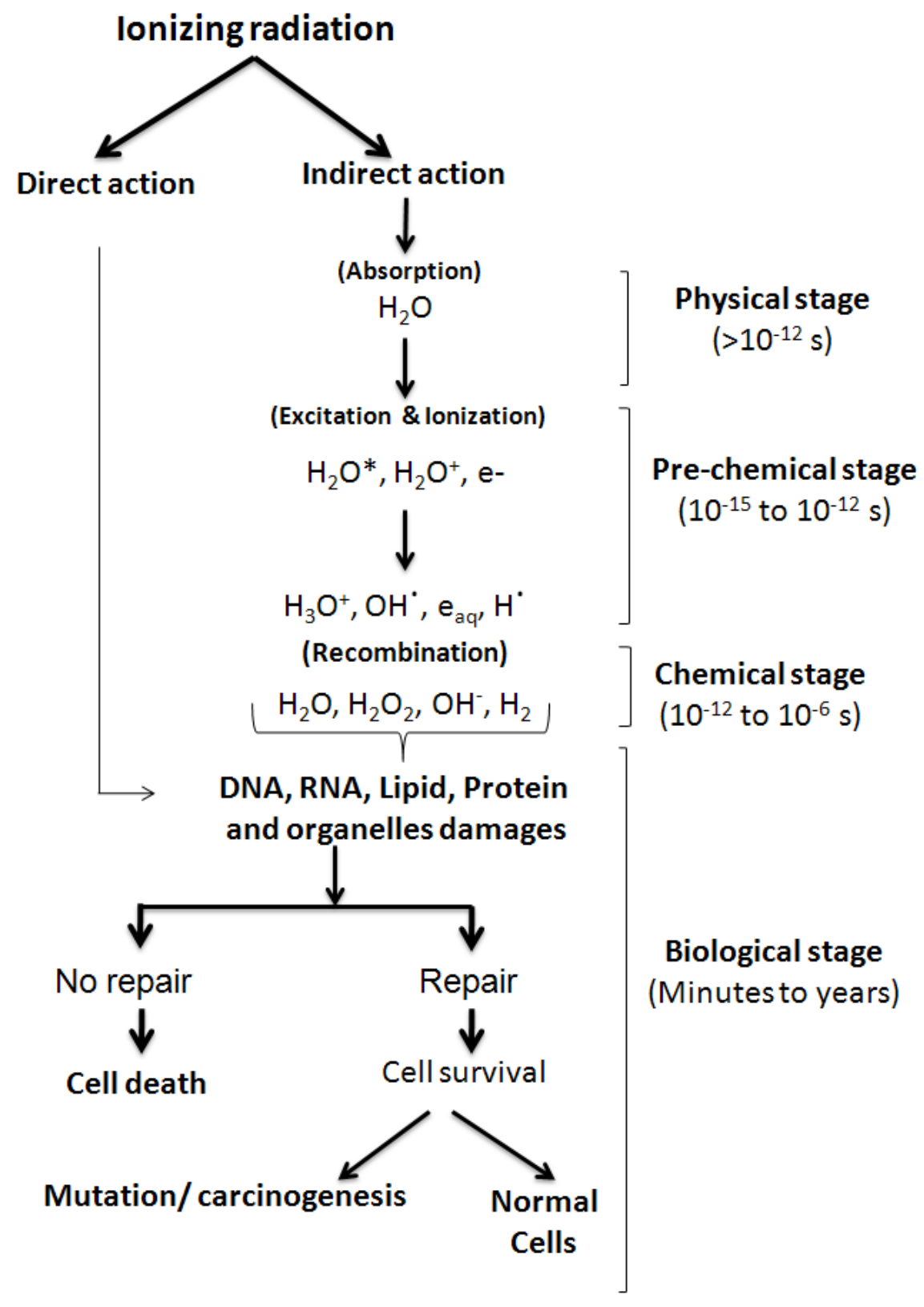

Fig. 1. Chain of the cellular event occurring in the cell/ tissue after ionizing radiation exposure. 


\section{Types of damages induced after radiation exposure}

Ionizing radiation can produce different types of damage to DNA, RNA, proteins and other biomolecules. DNA is the major target of radiation induced damage where as membrane is an alternative target. Because the portion of water in living matter is quite high, radiolytic product of the water, mainly hydroxyl radical is responsible for most damages to biomolecules. Hydroxyl radical causes damages to biomolecules by abstracting an $\mathrm{H}$-atom from the biomolecules (from the sugar moiety of the DNA or from the peptide chain of a protein) or by addition of the double bonds of aromatic moieties (DNA bases or aromatic moieties of protein side chain) (Spothem-Maurizot et al. 2008).

Ionizing radiation causes the formation of strand breaks in cellular DNA, as well as other types of lesions in the chromatin of cells(Roots et al. 1985). The amount of DNA damage induced is determined by type of radiation as well as the presence of other molecular components in close proximity to DNA, in particular the presence of proteins because it is well known that most molecular interactions between proteins and DNA occur via amino acids. It is estimated each gray (Gy) of radiation leads to about 100,000 ionizations within a cell, damage to over 1,000 bases, about 1,000 SSBs and about 20 - 40 DSBs. Despite this, 1 Gy kills only $30 \%$ of mammalian cells due to the effectiveness of DNA repair - particularly for non-DSB lesions (Spothem-Maurizot et al. 2008).

Lipid peroxidation has been found as the main damage to membrane lipids and lipoproteins. Ionizing radiation induced lipid oxidative modifications of poly unsaturated fatty acids (PUFAs) appears as a dynamic process initiated by hydroxyl free radicals generated by water radiolysis, amplified by a propagating-chain mechanism involving alkyl and peroxyl free radicals, and leading not only to hydroperoxides but also to a lot of other lipidic oxidized end-products, lipid hydroperoxides and conjugated dienes which are early products of lipid peroxidation (Spothem-Maurizot et al. 2008).

During ionizing radiation induced damage to protein, the type of reactions and consequences are quite similar to those of DNA; abstraction of $\mathrm{H}$ atoms and binding to aromatic rings, leading to backbone breakage and modification of side chains. All these event leads to peptide chain fragmentation and modification of amino acid side chain (e.g.Trp/formylkynurenine, Tyr/bityrosine,Cys/disulfide) (Spotheim-Maurizot and Davidkova 2011).

\section{Classification of radioprotective agents}

Radioprotective agent can be defined as "any agent that protects against radiation-induced damage, whether administered before, during, or after irradiation". They have been classified into three categories; i. Prophylactic agents, ii. Mitigators, and iii. Therapeutic agents (Stone et al. 2004). Prophylactic agents are administered before radiation exposure to prevent damage. 'Mitigators' designates agents that are administered during or after radiation exposure with the aim of preventing or reducing the action of radiation on tissues before the appearance of symptoms. These agents include decorporation and chelating agents that mitigate injury from internal radionuclide exposure. They also include blocking agents that mitigate the uptake of radionuclides by specific organs; for example, potassium iodide (KI) protects the thyroid from radioiodine. Therapeutic agents are administered after radiation exposure to treat or facilitate recovery from various aspects of the acute radiation syndrome (ARS) and delayed effects of radiation exposure(Weiss and Landauer 2009). The 
putative mechanism of radioprotection by plant and herbal radioprotectors may be mediated through several mechanisms, since they are complex mixtures of many chemicals (Jagetia 2007) but this may or may not be true with the pure compounds. Table 1 is a list of some radioprotective agents with their possible radioprotective properties.

\begin{tabular}{|c|c|c|}
\hline $\begin{array}{c}\text { Radioprotectors/ } \\
\text { mitigators and } \\
\text { therapeutics }\end{array}$ & Protective property & Ref. \\
\hline $\begin{array}{l}\text { Amifostine } \\
(\text { WR-2721) }\end{array}$ & $\begin{array}{l}\text { This is the most effective thiol protector still today. } \\
\text { Administration of WR-2721 intramuscularly (IM) at } 300 \mathrm{mg} / \mathrm{kg} \\
\text { in mice } 15 \mathrm{~min} \text { before radiation, a DRF of } 2.7 \text { was obtained with } \\
\text { protection observed when injected up to } 2 \mathrm{~h} \text { before irradiation. }\end{array}$ & (Kuna 1983) \\
\hline \begin{tabular}{|l|} 
Manganese (III) \\
tetrakis (N-methyl- \\
2-pyridyl)porphyrin \\
\end{tabular} & $\begin{array}{l}\text { Administration for } 14 \text { days at a daily dosage of } 5 \mathrm{mg} / \mathrm{kg} \\
\text { provided protection against oxidative damage and lethality in } \\
\text { mice exposed to total body irradiation (TBI). }\end{array}$ & $\begin{array}{l}\text { (Lee and Park } \\
\text { 2004) }\end{array}$ \\
\hline Melatonin & $\begin{array}{l}\text { Oral administration of } 20 \mathrm{mg} / \text { mouse (approximately } 800 \\
\mathrm{mg} / \mathrm{kg} \text { ) of melatonin } 30 \mathrm{~min} \text { before irradiation significantly } \\
\text { protected intestinal crypt cells. It inhibits chromosomal } \\
\text { aberrations and micronuclei formation in lymphocytes. When } \\
\text { melatonin treated mice were irradiated at an LD } D_{50 / 30} \text { dose }(8.15 \\
\text { Gy), survival increased to } 85 \% \text { in the group injected with } 250 \\
\text { mg/kg melatonin administered } 1 \mathrm{~h} \text { before irradiation. In a } \\
\text { model of acute lung injury in rats, administration of } 100 \mathrm{mg} / \mathrm{kg} \\
\text { melatonin before radiation exposure resulted in decreased } \\
\text { inflammation but promoted fibrosis. }\end{array}$ & $\begin{array}{l}\text { (Monobe et al. } \\
\text { 2005); } \\
\text { (Vijayalaxmi et } \\
\text { al. 1999); } \\
\text { (Vijayalaxmi et } \\
\text { al. 1996); (Serin } \\
\text { et al. 2007) }\end{array}$ \\
\hline ACE inhibitors & $\begin{array}{l}\text { They prevent the development of radiation-induced late effects } \\
\text { including damage to the kidney and lung. When the ACE } \\
\text { inhibitor perindopril was administered to mice for two days } \\
\text { before and two days after a lethal dose of gamma-radiation, a } \\
\text { significant increase in survival was observed ACE inhibition } \\
\text { accelerated hematopoietic recovery and increased the number of } \\
\text { hematopoietic stem cells. Protection was mediated by inhibition } \\
\text { of the angiotensin II pathway through the AT1 receptor because } \\
\text { similar effects were obtained with an AT1 receptor antagonist. }\end{array}$ & $\begin{array}{l}\text { (Charrier et al. } \\
\text { 2004; Moulder } \\
\text { and Cohen 2007) }\end{array}$ \\
\hline CDK4/6 inhibitors & $\begin{array}{l}\text { Entry into the cell cycle is mediated by cyclin-dependent kinase } \\
4 / 6 \text { (CDK4/6) activation, followed by CDK2 activation. Johnson } \\
\text { et al. have explored the role of cyclin-dependent kinase } \\
\text { inhibitors (CDKIs) in the control of the transition from G1 to S } \\
\text { phase in ionizing radiation-induced cell toxicity. They } \\
\text { confirmed that inhibitors specific for CDK4/6, specifically } \\
\text { PD0332991 and 2BrIC, caused reversible G1 arrest } \\
\text { (pharmacological quiescence) exclusively in Rb-positive and not } \\
\text { Rb-deficient human cells. They also reported that in mice, oral } \\
\text { administration of PD0332991 resulted in reversible inhibition of } \\
\text { proliferation of different populations of bone marrow cells. } \\
\text { Same group also found that PD0332991 markedly enhanced the } \\
\text { survival of mice, when applied as late as } 20 \text { h after total body } \\
\text { irradiation, thus, it acted as a radiomitigator. }\end{array}$ & $\begin{array}{l}\text { (Johnson et al. } \\
\text { 2010) }\end{array}$ \\
\hline $\begin{array}{l}\text { Growth factors } \\
\text { such as Palifermin, }\end{array}$ & $\begin{array}{l}\text { They are FDA approved growth factors. Palifermin specifically } \\
\text { decrease the incidence and duration of severe oral mucositis in }\end{array}$ & $\begin{array}{l}\text { (Spielberger et } \\
\text { al. 2004) }\end{array}$ \\
\hline
\end{tabular}




\begin{tabular}{|c|c|c|}
\hline $\begin{array}{l}\text { Radioprotectors/ } \\
\text { mitigators and } \\
\text { therapeutics }\end{array}$ & Protective property & Ref. \\
\hline Filgrastim & $\begin{array}{l}\text { patients with hematologic cancers undergoing high-dose } \\
\text { chemotherapy, with or without irradiation, followed by bone } \\
\text { marrow transplantation. }\end{array}$ & \\
\hline $\begin{array}{l}\text { Chelators such as } \\
\text { diethylenetriamene } \\
\text { pentaacetate } \\
\text { (DTPA) }\end{array}$ & $\begin{array}{l}\text { DTPA is a FDA-approved agents and includes the calcium and } \\
\text { zinc salts, used for the chelation of the transuranic radionuclides } \\
\text { plutonium, americium, and curium; Prussian blue for } \\
\text { decorporation of }{ }^{137} \text { Cs; and KI to block uptake of radioactive } \\
\text { iodine by the thyroid. }\end{array}$ & \\
\hline $\begin{array}{l}\text { Selenium } \\
\text { compounds such as } \\
\text { Selenomethionine } \\
\text { (SeM) and Sodium } \\
\text { selenite }\end{array}$ & $\begin{array}{l}\text { SeM is a naturally occurring derivative of selenium, found in } \\
\text { soya, grains, legumes, and selenium-enriched yeast (Whanger } \\
\text { 2002). When administered i.p., SeM }(4 \mathrm{mg} / \mathrm{kg} \text { Se) significantly } \\
\text { increased the survival of mice irradiated at } 10-\mathrm{Gy}{ }^{60} \text { Co at a low } \\
\text { dose rate }(0.2 \mathrm{~Gy} / \mathrm{min}) \text {. }\end{array}$ & $\begin{array}{l}\text { (Damron et al. } \\
\text { 2004; Diamond } \\
\text { et al. 1996) }\end{array}$ \\
\hline $\begin{array}{l}\text { Orientin and } \\
\text { vicenin from } \\
\text { Ocimum sanctum }\end{array}$ & $\begin{array}{l}\text { DRF for 30-days survival in mice treated } 30 \text { min before } \\
\text { irradiation with low doses }(50 \mathrm{mg} / \mathrm{kg}) \text { i.p. were } 1.30 \text { for orientin } \\
\text { and } 1.37 \text { for vicenin. The same low doses of orientin or vicenin } \\
\text { provided efficient protection against bone marrow damage, as } \\
\text { measured by chromosomal aberrations and stem cell survival } \\
\text { using the exogenous colony-forming unit spleen (CFU-S) assay. }\end{array}$ & $\begin{array}{l}\text { (Nayak and } \\
\text { Devi 2005; Uma } \\
\text { Devi et al. 2000) }\end{array}$ \\
\hline Genistein & $\begin{array}{l}\text { A DRF of } 1.16 \text { was obtained at a genistein dose }(200 \mathrm{mg} / \mathrm{kg} \mathrm{SC}) \text { that } \\
\text { did not result in any adverse pathology or behavioural toxicity. }\end{array}$ & $\begin{array}{l}\text { (Landauer et al. } \\
\text { 2003) }\end{array}$ \\
\hline
\end{tabular}

Table 1. A list of well known radioprotectors, mitigators and therapeutics.

\section{Role of radioprotectors in inhibition of DNA damages and enhancement of DNA repair after radiation exposure}

In order to restore the cellular function DNA repair is our important parameter that can be modified by radioprotective compounds to improve the radioprotection. Most of the cellular alterations induced by ionizing radiation is indirect and is mediated by the generation of free radicals and related reactive species, mainly derived from oxygen. Hence natural compounds with antioxidant activity have potential as good radioprotectors. Though a large variety of compounds have shown promise as radioprotector in laboratory studies, most of them failed even before reaching the preclinical stage due to toxicity and side effects.

Protection of cellular molecules including DNA from radiation can be achieved by various mechanisms. Protection to cellular DNA can be achieved by reducing the quantity of damage (by radical scavenging and chemical repair) followed by enhancement of biochemical repair of DNA to improved protection and recovery. Thus DNA repair is one of the important parameters that can be modified to attain improved protection. Many natural and related compounds are shown to be effective radioprotectors. They protect cellular molecules including DNA by various mechanisms. These include their antioxidant capacity and induction of repair mechanisms. Our studies have identified many compounds with radioprotective ability using in vitro, ex vivo and in vivo model systems. The systems used are rat liver and brain sub-cellular organelles, plasmid DNA, human lymphocytes, mammalian cells in culture and mouse. Different parameters also have been used to estimate damage and protection. Our studies have identified caffeine, chlorophyllin, 
flavonoid troxerutin, ferulic acid present in cereals, the food flavoring agent vanillin and tocopherol-mono-glucoside among others as effective radioprotectors. Details of some of these molecules are given below.

\subsection{Alpha tocopherol monoglucoside (TMG)}

TMG, a water-soluble derivative of Vitamin E, has been reported to be a good radioprotector with low toxicity (Kapoor et al. 2002; Nair et al. 2004; Rajagopalan et al. 2002). It has been reported that an oral administration of $2 \mathrm{~g} / \mathrm{kg}$ body weight of TMG, five minutes prior to radiation exposure, resulted in early recovery of the radiation-induced weight loss (Nair et al. 2003). Embryonic death, resulting from exposure to 2 Gy radiation in pregnant mice, was reduced by $75 \%$ with a single intra peritoneal injection of TMG $(0.6 \mathrm{~g} / \mathrm{kg}$ body weight) prior to the radiation exposure. However, the administration of TMG after the radiation exposure did not have any effect on the embryonic mortality (Nair et al. 2003). A single intra peritoneal injection of TMG $(0.6 \mathrm{~g} / \mathrm{kg})$ to mice, after whole body irradiation, elevated the $\mathrm{LD}_{50}$ (30) from 6 to $6.72 \mathrm{~Gy}$ (Nair et al. 2003). Radiation induced formation of micronucleated polychromatic and normochromatic erythrocytes in mouse bone marrow cells was inhibited by a single injection of TMG $(0.6 \mathrm{~g} / \mathrm{kg}$ body weight $)$ i.p. after the radiation exposure with a dose reduction factor of 0.5 (Satyamitra et al. 2001). Our in vitro studies, either with humans or mice, peripheral blood leucocytes showed that the presence of TMG $(0.5 \mathrm{mM})$ in post-irradiation incubation medium did not enhance the repair of DNA strand breaks(Salvi et al. 2007). TMG is also effective in preventing radiation-induced bone marrow death in mice and enhance hematopoietic recovery (Ueno et al. 2009), (Cherdyntseva et al. 2005).

\subsection{Baicalein}

Baicalein (scheme 2A), has been reported to possess lipid peroxidation inhibitory activity. Our results indicate that baicalein is a potent radioprotector at micromolar (5-50) levels. The protective effect, at $5 \mu \mathrm{M}$, was $80 \%$ against formation of thiobarbituric acid reactive substances (TBARS) and 50\% against lipid hydroperoxide. The protective ability against protein carbonyl formation was $50 \%$ and protein hydroperoxide formation $85 \%$ at the same concentration. Similar protective effects were also observed against damage to glutathione peroxidase and superoxide dismutase. A concentration dependent effect also was seen with most of the parameters examined. Single-strand break formation induced by radiation also was accentuated with baicalein. It also inhibited the DNA binding caused by radiation. (Tilak and Devasagayam 2003). Recently it was found that baicalein has a radioprotective effect against NF-kB-mediated inflammatory response through MAPKs and the Akt pathway (Lee et al. 2011).

\subsection{Caffeine}

Caffeine is a bitter, white crystalline xanthine alkaloid that is a psychoactive stimulant present in coffee and cola-based soft drinks. In humans, caffeine acts as a central nervous system (CNS) stimulant, temporarily warding off drowsiness and restoring alertness. We have shown that caffeine protected against DNA strand breaks in plasmid pBR322, a system devoid of repair and replication machinery (Kumar et al. 2001). This protective effect was related to the demonstrated antioxidant properties of caffeine in vitro, including scavenging of primary and secondary ROS (Devasagayam et al. 1996). Pretreatment with caffeine at 
doses of 5 or $15 \mathrm{mg} / \mathrm{kg}$, administered either i.p. or in drinking water, reduced radiationinduced frequency of chromosomal aberrations. Farooqi and Kesavan, had shown that administration immediately after radiation exposure also significantly reduced chromosome aberrations (Farooqi and Kesavan 1992). In our other study, George et al showed that when caffeine $(80 \mathrm{mg} / \mathrm{kg})$ was administered i.p. $1 \mathrm{~h}$ before irradiation it increases the survival of the mice (George et al. 1999). Radioprotection in mice at the same dose of caffeine may be related to modulation of radiation-induced apoptotic genes, for example, the depression of bax mRNA (Kim et al. 2003). This same high dose of caffeine protected against local radiation (35 Gy) skin reactions of mice. However, caffeine injection into a mouse fibrosarcoma did not affect the tumor response to irradiation (Hebbar et al. 2002).

\subsection{Chlorophyllin}

Chlorophyllin (CHL) (scheme 2B), is a water-soluble mixture of sodium-copper salts of green plant pigment, chlorophyll. CHL is widely marketed for a variety of dietary and medicinal uses. Recently, it has also been shown to occur naturally in a constituent of traditional Chinese medicine (Chiu et al. 2003). It has chemopreventive, antimutagenic and anticarcinogenic properties (Egner et al. 2001; Guo et al. 1995). Our lab has explored it radioprotective property in various model systems. It exhibited protection against radiation and chemical induced cytogenetic damage (Kumar et al. 1999)). CHL inhibited lipid peroxidation induced by 2,2'-azobis(2-propionimidinedihydrochloride) (AAPH) in lymphocytes in vitro. It also partially prevented radiation-induced suppression of mitogenic stimulation of lymphocytes in vitro (Kumar et al. 2004).

\subsection{Ferulic acid}

Ferulic acid (FA) (Scheme 2C) is a monophenolic phenylpropanoid occurring in plant materials such as rice, green tea and coffee beans. It is well known antioxidant and has ability to scavenge the free radicals. As for toxicity of this compound, no in vivo data is available, but in vitro cytotoxicity in rat hepatocytes showed an $\mathrm{LD}_{50}$ of $25 \mathrm{mM}$ (Maurya et al. 2005b). We have explored the effect of ferulic acid on gamma-radiation-induced relaxation of plasmid pBR322 DNA and induction of DNA strand breaks in peripheral blood leukocytes and bone marrow cells of mice exposed to whole body gamma-radiation. Presence of $0.5 \mathrm{mM}$ ferulic acid significantly inhibited the disappearance of supercoiled (ccc) plasmid pBR322 with a dose modifying factor (DMF) of 2.0. Intraperitoneal administration of different amounts (50, 75 and $100 \mathrm{mg} / \mathrm{kg}$ body weight) of FA $1 \mathrm{~h}$ prior to 4Gy gammaradiation exposure showed dose-dependent decrease in the yield of DNA strands breaks in murine peripheral blood leukocytes and bone marrow cells as evidenced from comet assay. The dose-dependent protection was more pronounced in bone marrow cells than in the blood leukocytes. It was observed that there was a time-dependent disappearance of radiation induced strand breaks in blood leukocytes (as evidenced from comet parameters) following whole body radiation exposure commensurate with DNA repair (Maurya et al. 2005b). Administration of $50 \mathrm{mg} / \mathrm{kg}$ body weight of FA after whole body irradiation of mice resulted disappearance of DNA strand breaks at a faster rate compared to irradiated controls, suggesting enhanced DNA repair in FA treated animals. When normal and tumor cells were treated with FA and the DNA damage measured after radiation exposure it was found that FA is having preferential protection to normal cells compared to tumor cells both under ex vivo and in vivo conditions (Maurya and Nair 2006). Recently, Ma et al have 
suggested that the radioprotective efficacy by FA may be a result of early recovery of hematopoietic cells due to enhanced production of G-CSF and erythropoietin (Ma et al. 2011a). They have also reported that FA had a radioprotective effect through the ERK pathway to inhibit apoptosis and oxidation (Ma et al. 2011b).

\subsection{Troxerutin}

Troxerutin (Scheme 2D), a derivative of the natural flavonoid rutin extracted from Sophora japonica (Japanese pogoda tree) has been commonly used in the treatment of Chronic Venous Insufficiency (CVI) disease (Lefebvre and Lacombe 1991). In clinical trials, troxerutin has been given in doses up to $7 \mathrm{~g}$ per day orally for up to 6 months with no contraindications (Glacet-Bernard et al. 1994). It has been reported that during radiotherapy of head and neck cancer, administration of a mixture of troxerutin and coumarin offered protection to salivary glands and mucosa. We have shown that troxerutin inhibited lipid peroxidation in membrane of sub-cellular organelles as well as normal tissues of tumorbearing mice exposed to gamma-radiation. Further, it was found that administration of troxerutin resulted in differential protection of DNA in blood leucocytes and bone marrow cells and not in cells of tumor in whole body irradiated tumor-bearing mice. Troxerutin protected the human peripheral blood leucocytes from radiation-induced DNA strand breaks in a concentration dependent manner under ex vivo condition of irradiation (2Gy)<smiles>O=c1cc(-c2ccccc2)oc2cc(O)c(O)c(O)c12</smiles>

A<smiles>CC1OC(OCC2OC(Oc3c(-c4ccc(OCCO)c(OCCO)c4)oc4cc(OCCO)cc(O)c4c3=O)C(O)C(O)C2O)C(O)C(O)C1O</smiles>

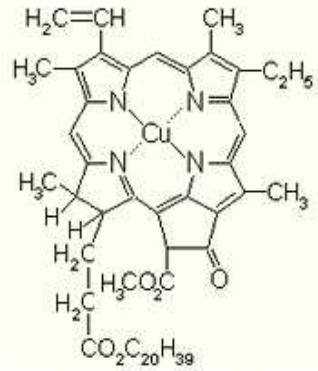

B<smiles>COc1cc(/C=C/C(=O)O)ccc1O</smiles>

C 
(Maurya et al. 2004). Intraperitoneal administration of troxerutin (175 mg/ kg body weight) to mice before and after whole body radiation exposure inhibited micronuclei formation in blood reticulocytes significantly. The administration of different doses (75, 125 and 175 $\mathrm{mg} / \mathrm{kg}$ body weight) of troxerutin $1 \mathrm{~h}$ prior to 4 Gy gamma-radiation exposure showed dose-dependent decrease in the yield of DNA strand breaks in murine blood leucocytes and bone marrow cells. The dose-dependent protection was more pronounced in bone marrow cells than in blood leucocytes. Administration of $175 \mathrm{mg} / \mathrm{kg}$ body weight of the drug (i.p.) 1 $\mathrm{h}$ prior or immediately after whole body irradiation of mice showed that the decrease in strand breaks depended on the post-irradiation interval at which the analysis was done. Measurement of DNA repair potential of the troxerutin shows that it enhances the DNA repair (Maurya et al. 2005a). So the observed time-dependent decrease in the DNA strand breaks could be attributed to enhanced DNA repair in troxerutin administered animals.

\subsection{Vanillin}

Vanillin (4-hydroxy-3-methoxybenzaldehyde), scheme 2E, is a compound used as a flavoring agent and as a dietary component. It is the major component of natural vanilla, which is one of the most widely used and important flavoring materials throughout the world. The source of vanilla is the bean, or pod, of the tropical Vanilla orchid (principally Vanilla planifolia Andrews, syn. V. fragrans (Salisb. Ames)). Vanillin is an antioxidant capable of protecting membrane against lipid peroxidation and DNA against strand breaks induced by reactive oxygen species like singlet oxygen. Vanillin and its analogs were strongly antimutagenic or anti-genotoxic in most studies. Vanillin also suppresses the chromosomal aberrations induced by X-rays in V79 cells in vitro (Keshava et al. 1998) and in mice in vivo (Sasaki et al. 1990). Imanishi et al. have shown anti-mutagenic effect of vanillin against UV and X-rays in Chinese hamster V79 cells (Imanishi et al. 1990). We have explored the effect of vanillin on radiation-induced DNA damage in plasmid pBR322 (in vitro), human peripheral blood leucocytes and mouse splenic lymphocytes (ex vivo) and in mouse (in vivo), besides the possible mechanisms involved in terms of scavenging radiation related free radicals by pulse radiolysis. Our finding shows that presence of $0.5 \mathrm{mM}$ vanillin has a dosemodifying factor (DMF) of 6.75 for $50 \%$ inactivation of ccc form. Exposure of human peripheral blood leucocytes (ex vivo) to radiation causes strand breaks in the cellular DNA, as assessed by comet assay. When leucocytes were exposed to $2 \mathrm{~Gy}$ of -radiation there was an increase in parameters of comet assay such as \%DNA in tail, tail length, 'tail moment' and 'Olive tail moment'. The presence of $0.5 \mathrm{mM}$ vanillin during irradiation significantly reduced these parameters. Damage to DNA in mouse peripheral blood leucocytes after whole-body exposure of mice (in vivo) to radiation was studied at 1 and $2 \mathrm{~h}$ post-irradiation. There was recovery of DNA damage in terms of the above-mentioned parameters at $2 \mathrm{~h}$ post-irradiation. This was more than that observed at $1 \mathrm{~h}$ (Maurya et al. 2007). The recovery was more in vanillin treated mice. Hence our studies showed that vanillin offers protection to DNA against radiation-induced damage possibly imparting a role other than modulation of DNA repair (Maurya et al. 2007).

\section{Future prospects for radioprotectors in mitigation of radiation damage}

Research in the development of radioprotectors worldwide has focused on screening a variety of chemical and biological compounds (Maurya et al. 2006; Nair et al. 2001; Weiss and Landauer 2009). Various natural or synthetic compounds having either antioxidant or 
cytoprotective or immunomodulatory property or their combination have been evaluated extensively for their radioprotective potentials in both in vitro and in vivo models (Maurya et al. 2006; Weiss and Landauer 2009). So far no synthetic radioprotective molecule is available that is perfectly safe and effective. Herbal origin radioprotectors have a hope to overcome the toxicity issues seen with the synthetic compounds. There are many reports on the pre-irradiation radioprotectors, using synthetic or natural compounds. There are hardly a few post-irradiation radioprotectors. Such radioprotectors based on induction of DNA repair and related mechanisms will have great potential in reducing accidental exposure such as those that occur due to natural calamities like earthquakes and tsunami as in the case of Fukushima daiichi nuclear reactors. To overcome this kind of situation, there is a need to locate more effective post-irradiation effective radioprotector that can enhance the DNA repair. Since the DNA is the critical target for ionizing radiation, future, studies should focus on compounds that have potential to enhance the process of DNA repair which is essential after radiation exposure. These also can be used in other cases of exposure such as that of radiotherapy for cancer.

\section{References}

Charrier, S., Michaud, A., Badaoui, S., Giroux, S., Ezan E, Sainteny, F., Corvol, P., \& Vainchenker, W. (2004). Inhibition of angiotensin I-converting enzyme induces radioprotection by preserving murine hematopoietic short-term reconstituting cells. Blood Vol.104, No.4, pp. 978-985

Cherdyntseva, N., Shishkina, A., Butorin, I., Murase, H., Gervas, P., \& Kagiya, T.V. (2005). Effect of tocopherol-monoglucoside (TMG), a water-soluble glycosylated derivate of vitamin E, on hematopoietic recovery in irradiated mice. Journal of Radiation Research, Vol.46, No.1 pp.37-41

Chiu LC, Kong CK, and Ooi VE. (2003). Antiproliferative effect of chlorophyllin derived from a traditional Chinese medicine Bombyx mori excreta on human breast cancer MCF-7 cells. International Journal of Oncology, Vol. 23, No.3, pp.729-735

Damron, T.A., Spadaro, J.A., Horton, J.A., Margulies, B.S., Strauss, J.A., \& Farnum, C.E. (2004). Novel radioprotectant drugs for sparing radiation-induced damage to the physis. International Journal of Radiation Biology, Vol. 80, No. 3, pp.217-228

Devasagayam, T.P., Kamat, J.P., Mohan, H., \& Kesavan, P.C. (1996). Caffeine as an antioxidant: inhibition of lipid peroxidation induced by reactive oxygen species. Biochim Biophys Acta, Vol. 1282, No 1, pp.63-70

Diamond, A.M., Dale, P., Murray, J.L., \& Grdina, D.J. (1996). The inhibition of radiationinduced mutagenesis by the combined effects of selenium and the aminothiol WR1065. Mutation Research, Vol. 356, No.2, pp.147-154

Egner, P.A., Wang, J.B., Zhu, Y.R., Zhang, B.C., Wu, Y., Zhang, QN., Qian, G.S., Kuang, S.Y., Gange, S.J, Jacobson, L.P., et al. (2001). Chlorophyllin intervention reduces aflatoxin-DNA adducts in individuals at high risk for liver cancer. Proceeding In National Academy of Science, U S A, Vol. 98, No.25, pp.14601-14606

Farooqi, Z., \& Kesavan, P.C. (1992). Radioprotection by caffeine pre- and post-treatment in the bone marrow chromosomes of mice given whole-body gamma-irradiation. Mutation Research, Vol. 269, No.2, pp.225-230

George, K.C., Hebbar, S.A., Kale, S.P., \& Kesavan, P.C. (1999). Caffeine protects mice against whole-body lethal dose of gamma-irradiation. Journal of Radiological Protection, Vol.19, No.2, pp.171-176 
Glacet-Bernard, A., Coscas, G., Chabanel, A., Zourdani, A., Lelong, F., \& Samama, M.M. (1994). A randomized, double-masked study on the treatment of retinal vein occlusion with troxerutin. Americal Journal of Ophthalmology, Vol. 118, No.4, pp.421429

Guo, D., Horio, D.T., Grove, J.S., \& Dashwood, R.H. (1995). Inhibition by chlorophyllin of 2amino-3-methylimidazo-[4,5-f]quinoline-induced tumorigenesis in the male F344 rat. Cancer Letters, Vol. 95, No.1-2, pp.161-165

Hebbar, S.A., Mitra, A.K., George, K.C., \& Verma, N.C. (2002). Caffeine ameliorates radiation-induced skin reactions in mice but does not influence tumour radiation response. Journal of Radiological Protection, Vol. 22, No.1, pp.63-69

Imanishi, H., Sasaki, Y.F., Matsumoto, K., Watanabe ,M., Ohta, T., Shirasu, Y., \& Tutikawa, K. (1990). Suppression of 6-TG-resistant mutations in V79 cells and recessive spot formations in mice by vanillin. Mutation Research, Vol. 243, No.2, pp.151-158

Jagetia, G.C. (2007). Radioprotective Potential of Plants and Herbs against the Effects of Ionizing Radiation. Journal of Clinical Biochemistry and Nutrition, Vol. 40, No.2, pp.74-81

Johnson, S. M., Torrice, C. D., Bell, J. F., Monahan, K. B., Jiang, Q., Wang, Y., Ramsey, M. R., Jin, J., Wong, K., Su, L., Zhou, D., \& Sharpless, N. E. (2010). Mitigation of hematologic radiation toxicity in mice through pharmacological quiescence induced by CDK4/6 inhibition. The Journal of Clinical Investigation, Vol 120, No. 7, pp.2528-2536.

Kapoor, S., Mukherjee, T., Kagiya, T.V., \& Nair, C.K. (2002). Redox reactions of tocopherol monoglucoside in aqueous solutions: a pulse radiolysis study. Journal of Radiation Research (Tokyo), Vol. 43, No.1, pp.99-106

Keshava, C., Keshava, N., Ong, T.M., \& Nath, J. (1998). Protective effect of vanillin on radiation-induced micronuclei and chromosomal aberrations in V79 cells. Mutation Research, Vol. 397, No.2, pp.149-159

Kim, J.K., Kim, J.H., \& Yoon, Y.D. (2003). Evaluation of caffeine as a radioprotector in wholebody irradiated male mice. In Vivo, Vol.17, No.2, pp.197-200

Kumar, S.S., Chaubey, R.C., Devasagayam, T.P.A., Priyadarsini, K.I., \& Chauhan, P.S. (1999). Inhibition of radiation-induced DNA damage in plasmid pBR322 by chlorophyllin and possible mechanism(s) of action. Mutation Research, Vol. 425, No.1, pp.71-79

Kumar, S.S., Devasagayam, T.P.A., Jayashree, B., \& Kesavan, P.C. (2001). Mechanism of protection against radiation-induced DNA damage in plasmid pBR322 by caffeine. International Journal of Radiation Biology, Vol. 77, No.5, pp.617-623

Kumar, S.S., Shankar, B., \& Sainis, K.B. (2004). Effect of chlorophyllin against oxidative stress in splenic lymphocytes in vitro and in vivo. Biochim Biophys Acta, Vol.1672, No.2, pp.100-111

Kuna, P. (1983). Duration and degree of radioprotection of WR-2721 in mice following its intraperitoneal, intramuscular and subcutaneous administration. Radiobiological Radiotherapy (Berl), Vol.24, No.3, pp.357-364

Landauer, M.R., Srinivasan, V., \& Seed, T.M.. (2003). Genistein treatment protects mice from ionizing radiation injury. Journal of Applied Toxicology, Vo. 23, No.6, pp.379-385

Lee, E.K., Kim, J.M., Choi, J., Jung, K.J., Kim, D.H., Chung, S.W., Ha, Y.M., Yu, B.P., \& Chung, H.Y. (2011). Modulation of NF-kappaB and FOXOs by baicalein attenuates the radiation-induced inflammatory process in mouse kidney. Free Radicical Research, Vol. 45, No.5, pp.507-517

Lee, J.H., \& Park, J.W. (2004). A manganese porphyrin complex is a novel radiation protector. Free Radical Biology in Medicine, Vol. 37, No.2, pp.272-283 
Lefebvre, G., \& Lacombe, C. (1991). Venous insufficiency in the pregnant woman. Rheological correction by troxerutin. Rev Fr Gynecol Obstet, Vol.86(2 Pt 2), pp.206208

Ma, Z.C., Hong, Q., Wang, Y.G., Tan, H.L., Xiao, C.R., Liang, Q.D., Lu, B.B., \& Gao, Y. (2011a). Effects of ferulic acid on hematopoietic cell recovery in whole-body gamma irradiated mice. International Journal of Radiation Biology. (doi:10.3109/09553002.2011.548438)

Ma, Z.C., Hong, Q., Wang, Y.G., Tan, H.L., Xiao, C.R., Liang, Q.D., Wang, D.G., \& Gao, Y. (2011b). Ferulic acid protects lymphocytes from radiation-predisposed oxidative stress through extracellular regulated kinase. International Journal of Radiation Biology, Vol.87, No.2, pp.130-140

Maurya, D.K., Adhikari, S., Nair, C.K.K., \& Devasagayam T.P.A. (2007). DNA protective properties of vanillin against gamma-radiation under different conditions: possible mechanisms. Mutation Research, Vol. 634, No.1-2, pp.69-80

Maurya, D.K., Balakrishnan, S., Salvi, V.P., \& Nair, C.K.K. (2005a). Protection of cellular DNA from gamma-radiation-induced damages and enhancement in DNA repair by troxerutin. Molecular and Cellular Biochemistry, Vol. 280, No.1-2, pp.57-68

Maurya, D.K., Devasagayam, T.P.A., \& Nair, C.K.K. (2006). Some novel approaches for radioprotection and the beneficial effect of natural products. Indian Journal of Experimental Biology, Vol. 44, No.2, pp.93-114

Maurya, D.K., \& Nair, C.K.K. (2006). Preferential radioprotection to DNA of normal tissues by ferulic acid under ex vivo and in vivo conditions in tumor bearing mice. Molecular and Cellular Biochemistry, Vol. 285, No.1-2, pp.181-190

Maurya, D.K., Salvi, V.P., \& Nair, C.K.K. (2004). Radioprotection of normal tissues in tumorbearing mice by troxerutin. Journal of Radiation Research (Tokyo), Vol. 45, No.2, pp.221-228

Maurya, D.K., Salvi, V.P., \& Nair, C.K. K.(2005b). Radiation protection of DNA by ferulic acid under in vitro and in vivo conditions. Molecular and Cellular Biochemistry, Vol. 280, No.1-2, pp.209-217

Monobe, M., Hino, M., Sumi, M., Uzawa, A., Hirayama, R., Ando, K., \& Kojima, S. (2005). Protective effects of melatonin on gamma-ray induced intestinal damage. International Journal of Radiation Biology, Vo. 81, No.11, pp.855-860

Moulder, J.E., \& Cohen, E.P. (2007). Future strategies for mitigation and treatment of chronic radiation-induced normal tissue injury. Seminal in Radiation Oncology, Vol. 17, No.2, pp.141-148

Nair, C.K.K., Parida, D.K., \& Nomura, T. (2001). Radioprotectors in radiotherapy. Journal of Radiatin Research (Tokyo), Vol. 42, No.1, pp.21-37

Nair, C.K.K., Salvi, V., Kagiya, T.V., \& Rajagopalan, R. (2004). Relevance of radioprotectors in radiotherapy: studies with tocopherol monoglucoside. Journal of Environmental Pathology, Toxicology and Oncology, Vol 23, No.2, pp.153-160

Nair, C.K.K., Devi, P.U., Shimanskaya, R., Kunugita, N., Murase, H., Gu, Y-H., \& Kagiya, T.V. (2003). Water soluble vitamin E (TMG) as a radioprotector. Indian Journal of Experimental Biology, Vol.41, pp.1365-1371

Nayak, V., \& Devi, P.U.( 2005). Protection of mouse bone marrow against radiation-induced chromosome damage and stem cell death by the ocimum flavonoids orientin and vicenin. Radiation Research, Vol. 163, No.2, pp.165-171

Rajagopalan, R., Wani, K., Huilgol, N.G., Kagiya, T.V., \& Nair, C.K.K. (2002). Inhibition of gamma-radiation induced DNA damage in plasmid pBR322 by TMG, a water- 
soluble derivative of vitamin E. Journal of Radiation Research (Tokyo), Vol. 43, No.2, pp.153-159

Roots, R., Kraft, G., \& Gosschalk, E. (1985). The formation of radiation-induced DNA breaks: the ratio of double-strand breaks to single-strand breaks. International Journal of Radiation Oncology Biology and Physics, Vol. 11, No.2, pp.259-265

Salvi, V.P., Maurya, D.K., Kagiya, T.V., \& Nair, C.K.K. (2007). Enhancement in repair of radiation-induced DNA strand breaks in vivo by tocopherol monoglucoside. International Journal of Low Radiation, Vol.4, No.1, pp.43-52

Sasaki, Y.F., Ohta, T., Imanishi, H., Watanabe, M., Matsumoto, K., Kato, T., \& Shirasu, Y. (1990). Suppressing effects of vanillin, cinnamaldehyde, and anisaldehyde on chromosome aberrations induced by X-rays in mice. Mutation Research, Vol. 243, No.4, pp.299-302

Satyamitra, M., Devi ,P.U., Murase, H, \& Kagiya, V.T. (2001). In vivo radioprotection by alpha-TMG: preliminary studies. Mutation Research, Vol. 479, No.1-2, pp.53-61

Serin, M., Gulbas, H., Gurses, I., Erkal, H.S., \& Yucel, N. (2007). The histopathological evaluation of the effectiveness of melatonin as a protectant against acute lung injury induced by radiation therapy in a rat model. International Journal of Radiation Biology, Vol. 83, No.3, pp.187-193

Spielberger, R., Stiff, P., Bensinger, W., Gentile, T., Weisdorf, D., Kewalramani, T., Shea, T., Yanovich, S., Hansen, K., Noga, S., et al. (2004). Palifermin for oral mucositis after intensive therapy for hematologic cancers. New England Journal of Medicine, Vol. 351, No.25, pp.2590-2598

Spotheim-Maurizot, M., \& Davidkova, M. (2011). Radiation damage to DNA in DNAprotein complexes. Journal of Physics: Conference Series 261 (2011) (doi:10.1088/1742-6596/261/1/012010)

Spothem-Maurizot, M., Mostafavi, M., Douki, T., \& Belloni, J., editors. (2008). Radiation Chemistry: from basics to applications in material and life science: EDP Science.

Stone, H.B., Moulder, J.E., Coleman, C.N., Ang, K.K., Anscher, M.S., Barcellos-Hoff, M.H., Dynan, W.S., Fike, J.R., Grdina, D.J., Greenberger, J.S., et al. (2004). Models for evaluating agents intended for the prophylaxis, mitigation and treatment of radiation injuries. Report of an NCI Workshop, December 3-4, 2003. Radiation Research,Vol. 162, No.6, pp.711-728

Tilak, J.C., \& Devasagayam, T.P.A. (2003). Radioprotective property of baicalein. BARC Newsletter, Vol. 249, pp.98-104

Ueno, M., Inano. H., Onoda, M., Murase, H., Ikota, N., Kagiya, T.V., \& Anzai, K. (2009). Modification of mortality and tumorigenesis by tocopherol-mono-glucoside (TMG) administered after $\mathrm{X}$ irradiation in mice and rats. Radiation Research, Vol. 172, No.4, pp.519-524

Devi, P.U., Ganasoundari, A., Vrinda, B., Srinivasan, K.K., \& Unnikrishnan, M.K. (2000). Radiation protection by the ocimum flavonoids orientin and vicenin: mechanisms of action. Radiation Research, Vol 154, No.4, pp.455-460

Vijayalaxmi, Meltz, M.L., Reiter, R.J., Herman, T.S., \& Kumar, K.S. (1999). Melatonin and protection from whole-body irradiation: survival studies in mice. Mutation Research, Vol. 425, No.1, pp.21-27

Vijayalaxmi, Reiter, R.J., Herman, T.S., \& Meltz, M.L. (1996). Melatonin and radioprotection from genetic damage: in vivo/in vitro studies with human volunteers. Mutation Research, Vol. 371, No.3-4, pp.221-228

Weiss, J.F., \& Landauer, M.R. (2009). History and development of radiation-protective agents. International Journal of Radiation Biology, Vo. 85, No.7, pp.539-573 


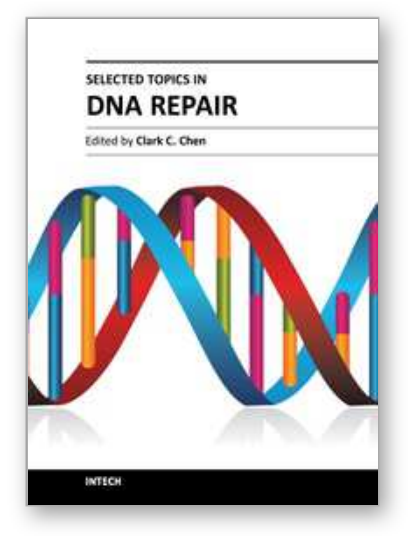

\author{
Selected Topics in DNA Repair \\ Edited by Prof. Clark Chen
}

ISBN 978-953-307-606-5

Hard cover, 572 pages

Publisher InTech

Published online 26, October, 2011

Published in print edition October, 2011

This book is intended for students and scientists working in the field of DNA repair, focusing on a number of topics ranging from DNA damaging agents and mechanistic insights to methods in DNA repair and insights into therapeutic strategies. These topics demonstrate how scientific ideas are developed, tested, dialogued, and matured as it is meant to discuss key concepts in DNA repair. The book should serve as a supplementary text in courses and seminars as well as a general reference for biologists with an interest in DNA repair.

\title{
How to reference
}

In order to correctly reference this scholarly work, feel free to copy and paste the following:

Dharmendra Kumar Maurya and Thomas Paul Asir Devasagayam (2011). Role of Radioprotectors in the Inhibition of DNA Damage and Modulation of DNA Repair After Exposure to Gamma-Radiation, Selected Topics in DNA Repair, Prof. Clark Chen (Ed.), ISBN: 978-953-307-606-5, InTech, Available from: http://www.intechopen.com/books/selected-topics-in-dna-repair/role-of-radioprotectors-in-the-inhibition-of-dnadamage-and-modulation-of-dna-repair-after-exposure-

\section{INTECH}

open science | open minds

\section{InTech Europe}

University Campus STeP Ri

Slavka Krautzeka 83/A

51000 Rijeka, Croatia

Phone: +385 (51) 770447

Fax: +385 (51) 686166

www.intechopen.com

\section{InTech China}

Unit 405, Office Block, Hotel Equatorial Shanghai

No.65, Yan An Road (West), Shanghai, 200040, China

中国上海市延安西路65号上海国际贵都大饭店办公楼 405 单元

Phone: +86-21-62489820

Fax: $+86-21-62489821$ 
(C) 2011 The Author(s). Licensee IntechOpen. This is an open access article distributed under the terms of the Creative Commons Attribution 3.0 License, which permits unrestricted use, distribution, and reproduction in any medium, provided the original work is properly cited. 